\title{
Prosthetic Aortic Valves: A Surgical and Bioengineering Approach
}

\author{
Dimosthenis Mavrilas ${ }^{1}$, Efstratios Apostolakis ${ }^{2}$ and Petros Koutsoukos ${ }^{3}$ \\ ${ }^{1}$ Mechanical Engineering \& Aer/tics, University of Patras, \\ ${ }^{2}$ School of Medicine, University of Ioannina, \\ ${ }^{3}$ Chemical Engineering, University of Patras,
}

Greece

\section{Introduction}

The need for replacement of damaged or malfunctioning organs or tissues in the human body has led through intense and innovative research during the past century to the development of materials and devices which are compatible with living tissues. Materials' compatibility consists in their capability to be accepted by the body when implanted and in contact with other tissues and body fluids. These materials, known as biomaterials, are the fundamental tools for engineering implantable devices dedicated to function in a specific way that substitutes corresponding function of the tissues or organs replaced due to malfunction, in synergism with the surrounding biological environment. Bone fracture healing by the incorporation of plates was known as early as the beginning of the century. Implants to replace heart valves and hip joints have been reported in the early 60s (Park \& Lakes, 1992). Among the problems recorded when the first implants were employed were corrosion, mechanical failure and rejection by the body. The latter remains the main problem in the development of novel biomaterials which can be used as implants. Biomaterials now play a major role in replacing or improving the function of every major body system (skeletal, circulatory, nervous, etc.). Commonly employed implants include orthopedic devices such as total knee and hip joint replacements, spinal implants, and bone fixators; cardiac implants such as artificial heart valves and pacemakers; soft tissue implants such as breast implants and injectable collagen for soft tissue augmentation; and dental implants to replace teeth/root systems and bony tissue in the oral cavity.

When a man-made material is placed in the human body, tissue reacts to the implant in a variety of ways depending on the material type and function. The mechanism of tissue attachment depends on the tissue response to the implant surface. In general, materials can be placed into three classes that represent the tissue response they elicit: inert, bioresorbable, and bioactive. Inert materials such as titanium and alumina $\left(\mathrm{Al}_{2} \mathrm{O}_{3}\right)$ are nearly chemically inert in the body and exhibit minimal chemical interaction with adjacent tissue. A fibrous tissue capsule will normally form around inert implants. Tissue attachment with inert materials can be through tissue growth into surface irregularities, by bone cement, or by press fitting into a defect. This morphological fixation is not ideal for the long-term stability of permanent implants and often becomes a problem with orthopedic and dental implant applications. Bioresorbable materials, such as tricalcium phosphate and polylactic- 
polyglycolic acid copolymers, are designed to be slowly degraded under the biologicalbiochemical action of the living organism in bioresorbable products (like water, ions of electrolytes or $\mathrm{CO}_{2}$ ), replaced by living tissue (such as bone or soft tissues in tissue engineering) or liberating drugs, as in drug-delivery applications. Bioactive materials bond to surrounding tissues (like bone or soft tissues) through a time-dependent, kinetic modification of the surface triggered by their contact and function after implantation with parts of living organism. In particular, ion-exchange reactions or ion incorporation into the crystal lattice between the bioactive implant and the surrounding body fluids results in the formation of a biologically active interface layer on the implant surface responsible for the relatively strong interfacial bonding.

\subsection{Anatomy of the normal aortic valve}

The aortic valve (figure 1) is composed of three components: the annulus, the cusps or leaflets and the commissures. The annulus of the valve, in contrast to this of atrioventricular valves, does not located at the same level. Here, the annulus consists of ventriculo-arterial junction and is oriented in a curvilinear, semilunar fashion. It consists of three almost semicircular dense fibrous collagen structures forming three scallops, the whole encircling the ventriculo-aortic junction like a coronet. The three aortic leaflets are folds of endocardium with a central lamina fibrosa, which is locally thickened. Each leaflet is attached to the aortic wall (its upper part) and to the left ventricle (its lowest part or nadir of

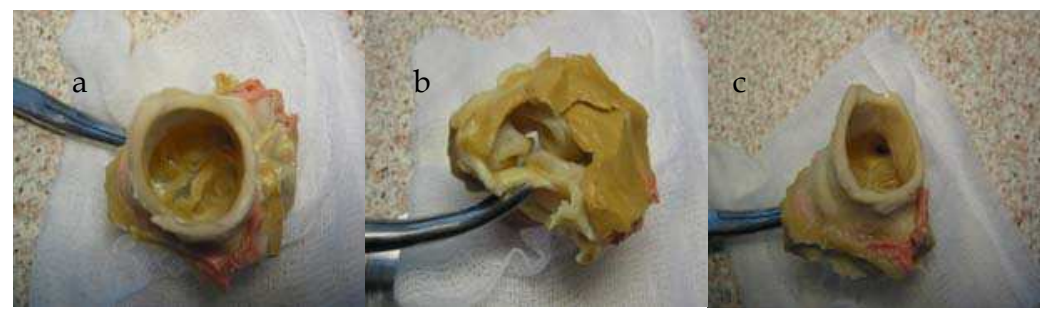

Fig. 1. Anatomy of aortic valve construct. a. View from aorta \& b. from left ventricle. c: View from aorta, showing leaflet junction, sinus of Valsalva and coronary ostium. Pictures are from a porcine aortic valve, of similar anatomy with human aortic valve
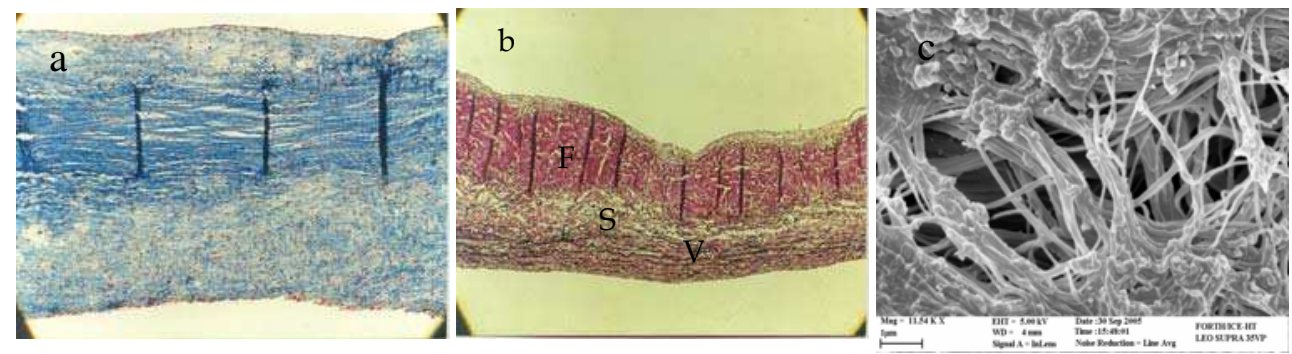

Fig. 2. Histological sections ( $a$ and b) and SEM microphotograph (c) of valvular leaflet tissue, demonstrating its multilaminate, 3D fiber reinforced composite structure, make it suitable for the complicated leaflet movements during valve function. F: Fibrosa, S: Spongiosa \& V: Ventricularis 
the leaflet). Leaflets are multilaminate composite tissue structures of 3 layers (Figure 2.): the ventricularis, composed of elastin- rich fibers aligned in a radial direction, perpendicular to the leaflet margin, the fibrosa, on the aortic side of the leaflet, comprising primarily fibroblasts and collagen fibers arranged circumferentially, parallel to the leaflet margin and the spongiosa, a layer of loose connective tissue at the base of the leaflet, between the fibrosa and ventricularis, composed of fibroblasts, mesenchymal cells, and a glycosaminoglycan (GAG) rich organic matrix. This composite tissue structure provides tensile strength and pliability to the leaflets for decades of repetitive motion per minute (Freeman \& Otto, 2005). The aortic surface of each leaflet is rougher than its ventricular surface.

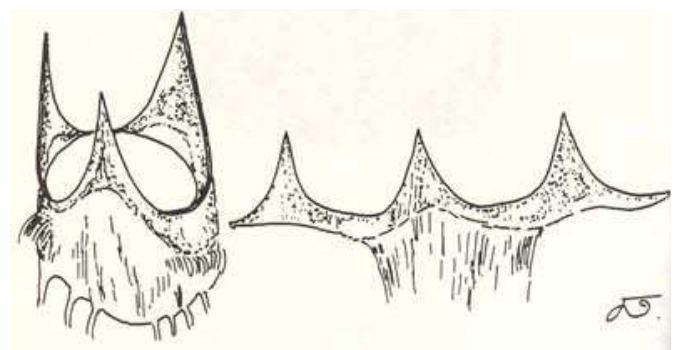

Fig. 3. Schematic representation of the three aortic valve commissures in natural and open configuration (acknowledged art work by G. Athanassiou)

The commissures (figure 3) form tall, peaked spaces between the attachments of neighbouring cusps, and reach the so-called aortic sino-tubular junction. The latter is a ridge, called also "supraortic ridge" that separates the sinus and tubular portions of the ascending aorta (Malouf et al., 2008). The commissure between the right and non-coronary (or posterior) aortic leaflet overlies the membranous septum and corresponds to that laid between the anterior and septal leaflets of the tricuspid valve (Malouf et al., 2008). The commissure between the right and left aortic leaflet contacts its corresponding pulmonary ones and overlies the infundibular septum. Finally, the intervalvular fibrosa, at the commissure between the left and non-coronary aortic leaflet, fuses the aortic valve to the anterior mitral leaflet (Edwards, 1996; Malouf et al., 2008).

\subsection{Physiology of the normal aortic valve}

During left ventricular systole, the systolic pressure inside rises exceeding the aortic pressure and the aortic valve is passively opened. Blood, ejected by the left ventricle (LV) pushes the aortic cusps upward and away from the centre of the aortic lumen. During this phase of cardiac cycle, the major opening diameter of the aortic valve is about equal to that of the ascending aorta at the level of sino-tubular junction (Stewart et al., 1998). In fact, the relatively inaccurate measurements of LV and intraaortic pressure during left ventricular catheterization show that there is no clinically significant gradient across the normal aortic valve. This measurement is curious because it suggests that blood does not travel down a pressure gradient during ejection. If flow out of the LV and through the outflow tract and the aortic valve was simply frictional, then a pressure gradient should needed between the LV and ascending aorta to obtain blood flow, according to the low of the physics: $\mathrm{Q}$ (flow)=Pressure Gradient/Resistance. However, this assumption does not hold when considering pulsatile blood flow in large vessels such as the aorta, since the inertia and 
momentum of the blood ejected from the LV is much more important than resistance. In fact, it has been experimentally shown that at the first $40 \%$ of the ejection phase, during blood acceleration, small pressure gradients (about $10 \mathrm{mmHg}$ ) are observed between LV and aorta (Hall \& Julian, 1989). This small gradient persists for about $45 \%$ of the ejection after which the gradient reverses as forward blood flow is decelerated.

The fibrous wall of the sinuses of Valsalva (figure 1) at the nadirs of annular scallops is not extensible in contrast to their upper parts (at the level of commissures) where it produces its biggest increase of aortic radius, about $16 \%$ in the peak of systole, due to the fibro-elastic composition of the aortic wall (Williams et al., 1989). During this phase the commissures move apart, making the fully open orifice triangular, the free margins of the aortic leaflets becoming almost straight lines between commissures. However, they do not flatten against the sinus wall, which is an important factor for the subsequent valve closure (Williams et al., 1989). Most of the blood ejected during systole is directed to the ascending aorta while a small volume enters into the sinuses of Valsalva. Valve geometry in the sinus region produces vortical blood flow at systole, which helps to coronary perfusion, maintain the triangular "mid-position" of the leaflets and probably initiate their re-approximation at the end of systole. During diastole, the three aortic leaflets fall passively towards the centre of the aortic lumen and, under the pressure of the supravalvular blood column they hermetically contact each other along lines of coaptation. Therefore during diastole the three normal aortic leaflets, such as the yacht-sails, support the entire intraaortic blood column and prevent its partial regurgitation into the left ventricle. Experiments have shown that only $4 \%$ of blood ejected during systole regurgitates through the centre of the valve during diastole. In the absence of sinuses of Valsalva the regurgitant blood may be increased up to 23\% (Williams et al., 1989).

\subsection{The diseased stenotic aortic valve}

Normal aortic valve histology and anatomy may be changed under pathologic conditions with corresponding alterations in its normal physiological function. Age-related changes in fibromuscular skeleton of the heart include myxomatous degeneration and collagen infiltration, called aortic valve sclerosis. This sclerosis is observed in as many as $30 \%$ of elderly people, namely in $25 \%$ of people 65 to 74 years of age and in $48 \%$ of people older than 84 years (Freeman \& Otto, 2005; Otto et al., 1999; Stewart et al., 1997). Histopathologic studies of aortic sclerosis show focal subendothelial plaquelike lesions on the aortic side of the leaflet that extend to the adjacent fibrosa layer. Similarities to atherosclerosis are present in these lesions, with prominent accumulation of "atherogenic" lipoproteins, including LDL and lipoprotein(a), evidence of LDL oxidation, an inflammatory cell infiltrate and microscopic calcification (Olsson et al., 1999; Otto et al., 1999; Wallby et al, 2002). The initiation of these lesions is possibly due to increased mechanical or decreased shear stress, similar to that seen in early atherosclerotic lesions (Freeman \& Otto, 2005). Of note, these changes are more prominent on the aortic surface of the leaflets where the mechanical stress of the aortic valve is highest, especially in the flexion area near the attachment to the aortic root. Shear stress across the endothelium of the non-coronary cusp is lower than the left and right coronary cusps because of the absence of diastolic coronary flow, which likely explains why the non-coronary cusp is often the first cusp affected (Freeman \& Otto, 2005).

Other age-related changes become in the valve, in the aortic wall, as well as in the myocardium. The central nodules on the cusps and the closure lines become more prominent. At the same time the Valsalva's sinuses are stretched, the diameter of the supra- 
aortic ridge increased and the surface area and mass of the aortic leaflets also increased (Hall $\&$ Julian, 1989). In the $6^{\text {th }}$ and $7^{\text {th }}$ decades the fibrosa of the leaflet begins to calcify, first at the point of attachment to the aortic wall, which is where maximum flexion occurs. This calcification may gradually extend throughout the valve, limiting the valve's opening. Occasionally, the calcified leaflets may develop local ulcerations and thrombus formations (Otto et al., 1999; Schwartz \& Zipes, 2005). Of course, in the cases of the rheumatic disease the course of chronic inflammatory disease produce the above-mentioned changes (calcification, thickening of the leaflets, fusion of commissures, local ulcerations, subendothelial atherosclerotic plaques, etc.) much earlier.

In normal adults, the area of the aortic valve orifice is 2.6 to $3.5 \mathrm{~cm}^{2}$. Experimental studies have suggested that the aortic orifice must be reduced to approximately one quarter of this in order to diminish significantly the cardiac output. A reduction in this area to $1 \mathrm{~cm}^{2}$ is associated with a rise in left ventricular systolic pressure and a pressure drop across the aortic valve (Hall \& Julian, 1989). Aortic stenosis is generally considered to be critical when the systolic pressure difference across the valve exceeds $50 \mathrm{mmHg}$ in the presence of a normal cardiac output or if the effective aortic orifice is less than $0.4 \mathrm{~cm}^{2}$ (Hall \& Julian, 1989). According to Rahimtoola, the aortic valve area has to be reduced by about $50 \%$ of normal before a measurable gradient can be demonstrated (Rahimtoola, 2004). When a pressure gradient develops between LV and aorta LV pressure is increased, ventricular wall stress increased contributing to development of myocardial hypertrophy and the LV function impairs. A diastolic dysfunction is caused of a combination of impaired myocardial relaxation during diastolic phase and increased myocardial stiffness (Hess et al., 1993). Patients with severe LV hypertrophy may exhibit LV diastolic dysfunction, which consequently may produce the syndrome of clinical heart failure with symptoms of paroxysmal nocturnal dyspnea, orthopnea or even pulmonary oedema, even if the systolic LV function is normal (Rahimtoola, 2004).

Prospective studies on the rate of hemodynamic progression in patients diagnosed with aortic stenosis documented an increasing rate of aortic jet velocity, in average $0.3 \mathrm{~m} / \mathrm{s}$ per year, with an increase in mean trans-aortic pressure gradient of $7 \mathrm{~mm} \mathrm{Hg}$ per year and a decrease in aortic valve area of $0.1 \mathrm{~cm}^{2}$ per year (Brener et al., 1995; Faggiano et al., 1996; Freeman \& Otto, 2005). During this later course, for the cases of symptomatic aortic stenosis or of the asymptomatic with significant $(>50 \mathrm{mmHg}$ ) trans-valvular mean gradient, surgical management is indicated.

\subsection{The surgical management of the stenotic aortic valve}

There are four options for the management of the severe calcific aortic stenosis: the balloon aortic valvuloplasty, the "open" aortic valve commissurotomy, the percutaneous aortic valve implantation, and the "classic" aortic valve replacement.

At balloon aortic valvuloplasty (BAV), a ballon-catheter is introduced after a femoral artery puncture and retrograde till the left ventricle (Diethrich, 1993; Smedira et al., 1993). Inflation of the balloon within the aortic orifice can stretch the calcified annulus, fracture calcified areas and dissect the fused commissures. Disadvantages of the method, as the risk of stroke and increase of pre-existent valve regurgitation (Cormier \& Vahanian, 1992) are controversial to increase of effective orifice area. An overall $65 \%$ survival and $40 \%$ free of death or reoperation over 1-year survival has been reported (Davidson et al., 1990). However, no beneficial effect on long-term clinical outcome demonstrated due to significant residual obstruction from leaflet thickening and annular calcification, resulted in severe re-stenosis 
typically occurred within months (Bonow et al., 1998; Cormier \& Vahanian, 1992; Freeman \& Otto, 2005; Smedira et al., 1993).

The "open" aortic valvulotomy, performed rarely, usually during another open heart operation, is based on the -by a scalpel- commissurotomy of the fused commissure (-s). Because of the excessive calcification and rigidity of the leaflets, a central postoperative insufficiency is anticipated. The main indication is the case of congenital aortic stenosis with one or two congenitally fused commissures. In fact, in young patients, if the valve is pliable, mobile, and free of calcification, simple commissurotomy may be feasible. The operative mortality in these cases does not exceed 1\% (Rahimtoola, 2004).

The impetus for the development of percutaneous or transcatheter aortic valve replacement (PAVI or TAVI) lies in the need for an intervention that is more durable than balloon aortic valvuloplasty and that can be used in patients who are too risk for the "classic" aortic valve replacement. The basic concept is based on the use of an outer expandable stent (scaffold) to resist the rigidity of the calcified aortic annulus and native leaflets (Davidson \& Baim, 2008). In the inner surface of this stent three appropriately prepared pericardial or porcine leaflets are fixed constituting -after full expansion of the stent- a well functioning valvular prosthesis. The first implantation in the human being was done in France since 1992 by Cribier et al. (Cribier et al., 2002). The introduction of the catheter bearing the valved-stent requires direct femoral or iliac artery access, while in a few cases with stenotic iliac arteries the catheter is introduced through the apex of the left ventricle (transapical introduction), after a left anterior thoracotomy. The results of this method after more than 10 years of application are encouraged. Procedural mortality is $2-3 \%$, one-month survival about $88 \%$ and the 1-year is ranged 65 to $78 \%$ (Bosmans et al., 2011).

Finally, the aortic valve replacement is the "classical" surgical treatment of calcific aortic stenosis, especially for the elderly. During this method, the three calcified leaflets of the valve are resected, as well as the calcific deposits of the annulus. Then, sutures are passed circumferentially through the annulus and the sewing ring of the prosthesis. Finally, the sutures are tied down in the native annulus. Aortic valve replacement by using $3^{\text {rd_ }}$ generation prosthetic valves -mechanical or biological- obtains excellent early and late outcomes with low mortality and morbidity. Recent surgical series report operative mortality rates for aortic valve replacement as low as $1 \%$, increasing to $9 \%$ in higher-risk patients. Long-term survival after valve replacement is $80 \%$ at 3 years, with an age-corrected survival postoperatively that is nearly normalized (Freeman \& Otto, 2005; Rahimtoola, 2010). Significant postoperative morbidity, such as thromboembolism, hemorrhagic complications from anticoagulation, prosthetic valve dysfunction, and endocarditis, are rare and occur at a rate of $2 \%$ to $3 \%$ per year (Rahimtoola, 2010).

\section{Aortic valve prostheses: The parallel evolution of mechanical \& bioprosthetic valves}

Cardiac valve prostheses are devices designed and constructed properly to assure unidirectional blood flow. Like the natural cardiac valves, they work passively, due to pressure difference across their structure, with parts able to be moved between two positions: open position, when blood circulates, as in the case of aortic valves from left ventricle to the aorta during myocardial contraction (systolic phase) and closed position, when blood circulation stops (during the diastolic phase for the aortic valve). From a 
mechanical point of view, cardiac valves work as common one-way valves of hydraulic systems. Despite their simple working principle, the design and orthotopic surgical implantation of cardiac valves was not possible till the development of extracorporeal blood circulation devices, introduced by Gibbon (Gibbon, 1954), by which blood circulation was maintained during open heart surgical procedures. Two main types of prosthetic heart valves are available: Mechanical (MHV) and biological or bioprosthetic (BHV) heart valves. MHVs in general composed of two main parts: One non-moving, which is sutured properly in the anatomic region of the failed, surgically excised, natural valve, in the interior region of which a second, moving part is included, passively guided by pressure difference changes between the inlet and outlet regions around it. The main difference is on the type of the moving part (occluder): The ball type and the disk type valves. For each of the two basic constructions many different designs and materials were used and a great branch of technology was developed. In a near parallel approach, BHVs, based on mimicking the design and function of natural heart valves were developed and applied. Although they simply were made of animal derived valves of proper size and structure, like porcine aortic valves, after biochemical treatment for removing antigenic factors, different designs have been introduced nowadays using combinations of artificial and natural derived biomaterials.

\subsection{Evolution of mechanical heart valve prostheses}

Different surgical operations were approached before extracorporeal circulation by implantation of artificial valve designs in peripheral vessels, like that of Hufnagel \& Harvey in 1952 (Hufnagel \& Harvey, 1953), when an aortic valve, made by a combination of biologically inert materials (a lucite ${ }^{\circledR}$ tube-like design with a mobile spherical poppet inside) was implanted in the descending thoracic aorta of a patient with a significant aortic insufficiency. However, it was at end of 50s when a caged ball type MHV was introduced. This design, in its final appearance, consists of a metallic ring with a soft material in its perimeter for stable suturing on surrounding soft tissues without blood leakage through the suturing line. A cage design, usually a three metal struts, is welded in the ring into which a ball made of silicon or other polymeric material is moved from the closed position, where it is pushed in touch with the ring, to the open once where it is attached the top of the cage (figure 4a). Starr and co-workers began in 1960 (their first report appeared in 1963) (Starr et al., 1963) to implant the caged ball aortic prosthesis in the orthotopic position with many of these prostheses remained well functioning for up to 40 years (Shiono et al., 2005). Major problems with these initial so-called "ball valves" were the compromised hemodynamic performance (small effective orifice area, big size of the sewing ring, turbulent flow) and the thromboembolic complications (high-grade haemolysis, thrombosis). For the last reason, all these valves required intense anticoagulation therapy (Ezekowitz, 2002).

To find a solution in these problems, after a substitution of ball with a disk type occluder (caged disk valves) to achieve less moving mass and reducing the valve height inside the aortic root, the second-generation of prosthetic valves, the so-called "tilting-disk valve", was developed in 1968 (Emery et al., 2008) (figure 4b). Tilting disk valves were the result of evolution in MHV technology towards reduction of whole volume, occluder mass and surface area projected vertical to the blood flow axis, maximizing of opening angle of the disk and designed the disk shape so as to approach a near physiological central flow velocity profile. Haemocompatibily was also improved by a minimization of the blood 
contact area, material coating with biocompatible compounds (like pyrolitic carbon) and appropriate disk morphology for smoother blood flow around it. The most usable models were the Björk-Shiley and the Medronic Hall type. The main problems with these valves were the rare rupture of metal strut supporting disk movement and subsequent embolisation by the disk, non-axial flow, even in the models of Björk-Shiley with disk opening angle of $72^{\circ}$. Due to the excessive turbulent flow through the two orifices of the valve (a small and a bigger), a high-grade of haemolysis in patients was reported. However, good long-term results characterized that type of MHV (Oxenham et al., 2003).

The $3^{\text {rd }}$ generation of mechanical valves was appeared in 1977 with the introduction of the St. Jude Medical (SJM) bileaflet valve coated with pyrolitic carbon (Emery et al., 2008; Gott et al., 2003). Over the following decades, the dramatic step of bileaflet prostheses nearly obviated the use of all other kinds of mechanical valves in all over the world (Emery et al., 2008). In fact, the low-profile SJM valve demonstrated low rates of thomboembolism, low trans-valvular gradients, low grade of haemolysis and minimal valvular insufficiency (Chambers et al., 2005; Gott et al., 2003; Walther et al., 2000). Out of the SJM valve, several other $3^{\text {rd }}$ generation models were introduced such as the ATS Medical Prosthesis, the Sulzer CarboMedics, the On-X prosthesis and the Sorin prosthetic valve, all of them with similar haemodynamic and clinical outcomes (Chambers et al., 2005; Walther et al., 2000). Since the introduction of this $3^{\text {rd }}$ generation of the valves and till over 2.1 million of these models have been implanted all over the world. In the meantime, many useful changes in valve design have been made in the new models. There are many changes on the effective flow orifice area, on the shape of the leaflets (straight, convex or concave), on the pivot style, on the angle of orientation of the leaflets (from $72^{\circ}$ to $90^{\circ}$ ), on the sewing-ring etc. (Chambers et al., 2005; Gelsomino et al., 2002; Gott et al., 2003; Walther et al., 2000).
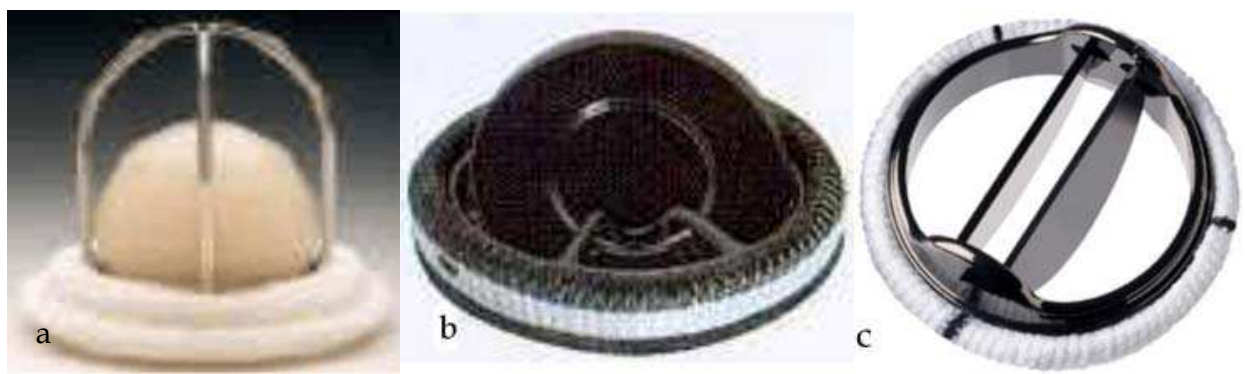

Fig. 4. Three generations of mechanical heart valves: a. caged ball, b. tilting disk \& c. bileaflet mechanical heart valves

\subsection{Evolution of bioprosthetic heart valves}

Heart valve transplantation is the substitution of the diseased heart valves with healthy living heart valves (valves transplanted from genetically similar donors-homologous valves), including auto transplantation (the substitution of the aortic valve with the pulmonary valve and the later with a prosthetic non-living valve - the Ross procedure). Murray in 1956 demonstrated that human aortic valves from cadavers could be used as a valve transplant in the descending thoracic aorta in patients with aortic insufficiency (Murray, 1956). Based on this research Kerwin and co-workers six years later reported their first clinical applications in patients, with one of them having 6-year follow-up (Kerwin et 
al., 1962). The first orthotopic insertion of homograft valve was performed in 1962 by Barratt-Boyes (Barratt-Boyes, 1964). The introduction of other biological valves began in 1967 when Senning used pieces of fascia lata of the patient for replacement of the diseased aortic valve (Senning, 1967; Ionescu \& Ross, 1969).

Xenograft or heterograft valves, animal derived heart valves or BHVs made from different animal derived tissues are alternatives, offering the advantage of been prepared much prior the operation, available in different sizes and designs. BHVs include a variety of heart valve replacement using as substitutes heart valves of different orientations and technologies. Among different types, porcine aortic and bovine pericardial xenograft BHVs has been established as valve substitutes. Porcine aortic valves, after a treatment for removing excess fatty and aortic wall tissue and part of septal myocardial tissue from valve leaflets are imposed in biochemical preparation, aimed in removing antigenic factors (valve cells) and stabilize the remaining acellular valve tissue against enzyme reactions by different chemical compounds. Formaldehyde was first used for porcine valve fixation (Angel, 1972), substituted later by glutaraldehyde because of its ability for double-edge cross linking of collagen molecules (Woodroof, 1972), resulted in better longevity of valves. The stabilized tissue valve is sutured in specially designed frames composed of aortic ring and three commissures. A metallic or polymeric frame is used as a skeleton, covered with biocompatible textiles (like Teflon ${ }^{\circledR}$ or Dacron ${ }^{\circledR}$ ) onto which the valve tissue is sutured with permanent sutures).

Improvement of BHV function was achieved with the use of different membranous soft tissues for the construction of valve leaflets and suturing them in similar artificial frames like that of the porcine valves. Percutaneous tissue was used for that scope; however, pericardial tissue from different animals was finally used alternatively. Pericardial tissue is a big membrane enclosing the heart. Its histology is similar to heart valve leaflets with respect of its composition of collagen and elastin fiber networks in different layers inside an amorhous organic matrix of glycosaminoglycans (GAGs), proteoglycanes (PGs), and other proteins. Extracellular water solution of electrolytes and soluble proteins compose $65-70 \%$ of the tissue mass weight. Cells, like fibroblast, epithelial, muscle cells and other types are present. Despite these similarities with other soft tissues, including heart valve leaflets, fibber structure of bovine pericardium is quite different. Fibber orientation in valve leaflets is specified for supporting their motion and strengthening mechanical stress developed during valve function. The different anatomic position and function of pericardial tissue resulted in a different fibber orientation, varied across its surface. For this reason special attention is given in selection criteria of specific regions from the whole pericardial membrane for better suitability to function as heart valve leaflets (Simionescu et al., 1993). The benefits from the use of pericardial tissue (especially bovine ones, which is the standard selection last years) instead of porcine valves were better opening area of the valve, coaptation of the valve leaflets and flexibility in design of valve anatomic configuration. However, similar problems with porcine BHVs, tissue deterioration and calcification still remain.

The first xenograft valve, a stent-mounted porcine aortic valve was implanted by Binet et al. in 1965 (Binet et al., 1965), while the glutaraldehyde-preserved stent-mounted porcine valves were introduced by Carpentier et al., in 1967 (Carpentier et al., 1969). Over the past 40 years, advances in tissue fixation (bovine pericardium and porcine aortic valves) methodologies and chemical treatments to prevent calcification, have yielded improvements in the longevity of bioprostheses. 
Like the mechanical valves, the development of biologic valves is characterized by the appearance of first-, second-, and third-generation prostheses. First-generation bioprostheses were preserved with high-pressure fixation. They include the Medtronic Hancock Standard, and the Carpentier-Edwards Standard valves, both porcine prostheses. Second-generation prostheses are treated with low-, or zero-pressure fixation. Pericardial prostheses include the Carpentier-Edwards Perimount, and the Pericarbon Sorin prostheses. Porcine prostheses include the Medtronic Hancock II, the Medtronic Intact, and the Carpentier-Edwards Supraannular prostheses. In the third-generation prostheses were included all valves with zero-, or low-pressure fixation, decellularization of animal tissues and simultaneous antimineralization processes (e.g. a-amino oleic acid) to reduce material fatigue and calcification. In these models the stents have become gradually thinner and flexible, the profile much lower and the effective orifice area larger. Porcine prostheses include the Medtronic Mosaic, and the St. Jude Medical Epic valve. Pericardial prostheses include the Carpentier-Edwards Magna and the Mitroflow Pericardial valve.

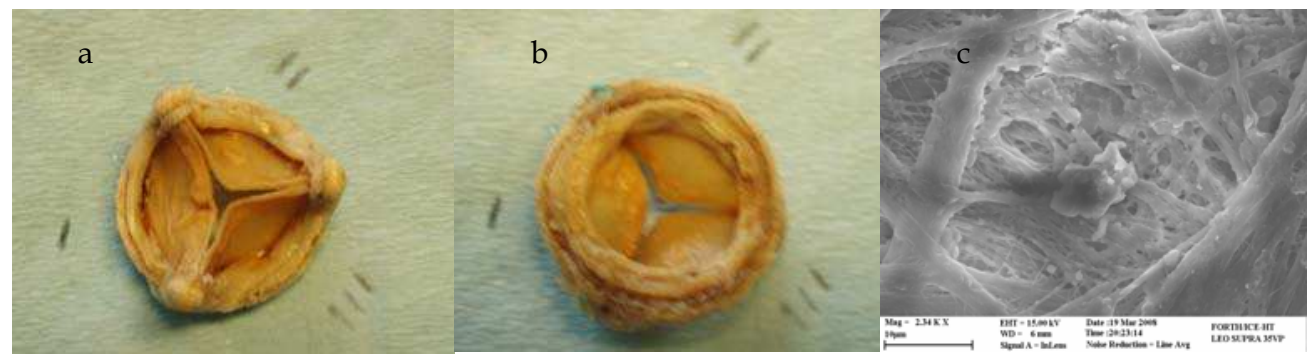

Fig. 5. Pericardial bioprosthetic heart valve explanted due to severe calcification. A: aortic side, b: ventricular side, c: SEM micrograph of the same valve demonstrating calcific crystals deposited implemented with leaflet tissue fibber network

\subsection{Comparison of MHV with BHV replacement}

Aortic valve replacement by using a mechanical prosthetic valve is not indicated for all patients suffered from aortic valve stenosis. Generally, the two main advantages of the mechanical valves are the absence of degeneration (long-term rigidity) and the larger effective flow orifice, both contributing to better long-term outcomes. In fact, according to many studies followed over time frames, freedom from all-valve related events and from the risk of reoperation were improved in patients with mechanical valve prostheses as compared to those with biologic prostheses (Ezekowitz, 2002; Gott et al., 2003). On the other hand, the main disadvantage of mechanical valves is the obligatory need for long-life anticoagulation (Ezekowitz, 2002). The use of porcine BHVs resulted in a better function in patient circulatory system, improving failed valve insufficiency due to stenosis or regurgitation of diseased natural valves. A central blood flow with a near physiological velocity profile, low pressure gradient across the valve, near physiological leaflet movements and no need for long term anticoagulation therapy were the benefits of their use. However, porcine BHVs longevity remains limited, mainly because of calcification of valve leaflets. Calcific crystal deposits are gradually developed in valve leaflets caused stiffening and incompetence in their moving ability and valve dysfunction due to stenosis or regurgitation. BHV calcification is more often in younger patients, for which MHVs are the gold standard in heart valve replacement. 


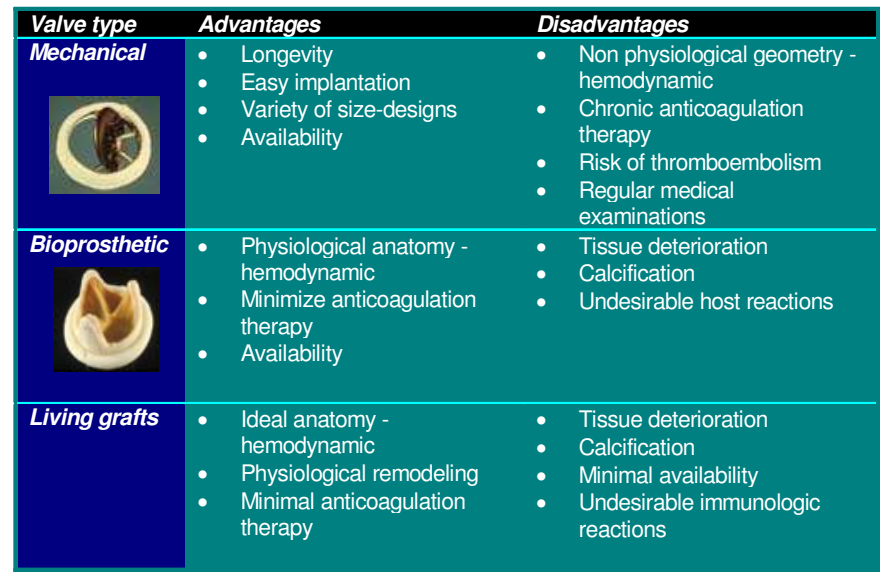

Table 1. Comparison of different types of heart valve substitutes

A mechanical valve prosthesis is recommended to patients having valve re-operation, regardless of the nature of the first operation, as the risk of the second operation is significantly higher (Gelsomino et al., 2002; Potter et al., 2005). The most debated age for making decision according the selection of type of prosthesis is the decade between 60 and 70 years. The final decision is dependent on other parameters, which have to be taken into account, like the existence of atrial fibrillation, chronic renal failure, cerebrovascular disease, history of gastrointestinal bleeding, contraindication to oral anticoagulants, etc. (Emery et al., 2002).

In 1962, D. Harken summarized the 10 important characteristics that an ideal heartc valve must satisfy:

1. Not propagate emboli.

2. Be chemically inert and not damage blood elements.

3. Offer no resistance to physiological flows.

4. Close promptly (less than 0.05 second).

5. Remain closed during the appropriate phase of the cardiac cycle.

6. Lasting physical and geometric features.

7. Be inserted in a physiological site, generally the normal anatomical site.

8. Be capable of permanent fixation.

9. Not annoy the patient.

10. Be technically practical to insert (Harken et al., 1962).

After a near 50 years of evolution today's mechanical or biological valve do not satisfy all those requirements.

\section{Biomechanics of heart valve prostheses}

During their motion natural valve leaflets imposed to different mechanical loading and corresponding stress fields. Mechanical bending is developed during opening especially at sites near their attachments to valvular ring, while shear stress is gradually developed at their sides faced blood flow. A near parabolic velocity profile is produced in fully developed central axial blood flow across the valve which fast stabilizes leaflets in a position parallel to its axis. Upon starting of closing phase of the valves a reverse leaflet movement is 
performed with changing stress fields applied to their structure, till the closing position during which these membranous tissues, supported at their sites of attachment on valvular rings and their coaptation areas, are imposed in surface tensile loading, while obstructing blood backflow and big pressure differences between their sides. As a result of all these different mechanical loadings imposed, leaflet tissue is remodelled in a multilaminate, anisotropic (see diagram in figure 6) reinforced composite biomaterial, demonstrating a structure of multilayered 3D collagen and elastin fibrous networks, integrated and moved into an amorphous organic protein matrix, filled with cells and extracellular water, electrolytes and soluble proteins of low molecular weight. This tissue structure, different in individual valve leaflets, is specifically able to function at the specific anatomic position. Been in a different position, like, for example, from pulmonary artery to aorta as in Ross procedure, tissue remodelling started to make the pulmonary valve leaflets able to resist higher mechanical loading in aortic position, compared with that of pulmonary circulation.

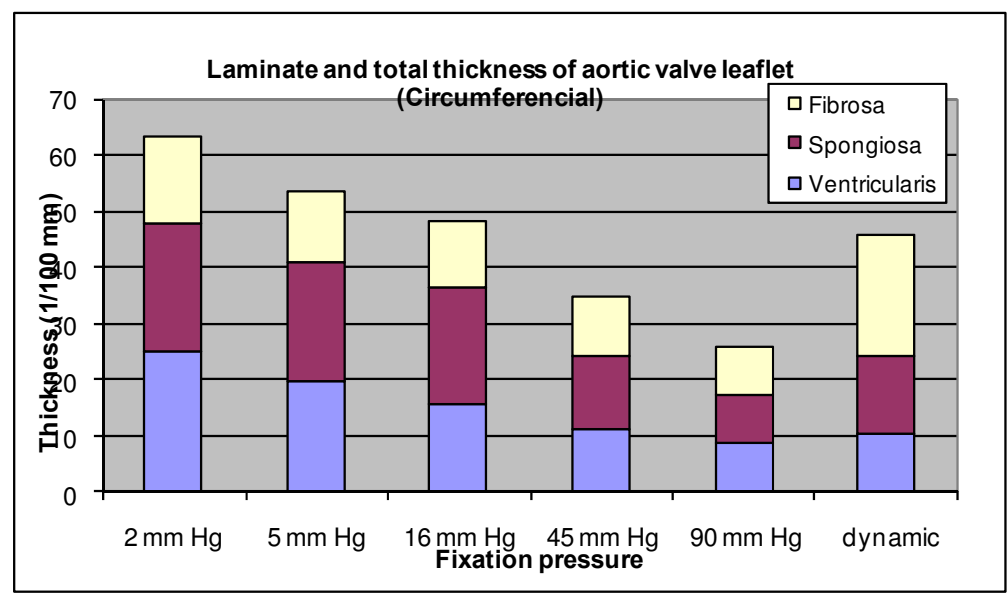

Fig. 6. Diagram (from measurements in histological sections) of the laminate and total leaflet thickness changed under different pressure levels applied during their fixation with glutaraldehyde. In dynamic mode, the valve was under normal function during fixation. Anisotropic deformation of the different tissue laminates is demonstrated as pressure increases

Natural heart valve leaflets exhibit non linear viscoelastic mechanical behaviour under mechanical loading (figure 7a). A similar mechanical behaviour is demonstrated by tissue heart valves of all species, as well all membranous soft tissues. Chemical modification of bioprosthetic heart valves, needed for removing antigenic factors and stabilization against enzyme biodegradation, resulted in significant stiffening of leaflet tissue compared with its natural state, as demonstrated by increase of high (collagen) modulus (figure $7 \mathrm{~b}$ ).

Other viscoelastic mechanical parameters of valve leaflet tissue, like low (elastin) modulus (the slope of the first linear part of the loading stress-strain curve (fig. 7a)) and relaxation index may also changed, although hysteresis, another viscoelastic characteristic of membranous soft tissues (defined as the ratio of dissipated to the loading energy in every loading-unloading cycle) demonstrating energy dissipation inside the tissue during cyclic deformation, measured at $20 / 35 \%$ of loading energy depending on cyclic frequency seems to be unchanged after chemical modification. 


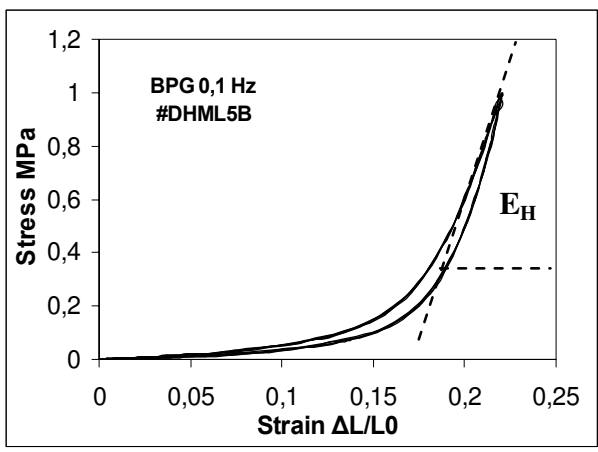

(a)

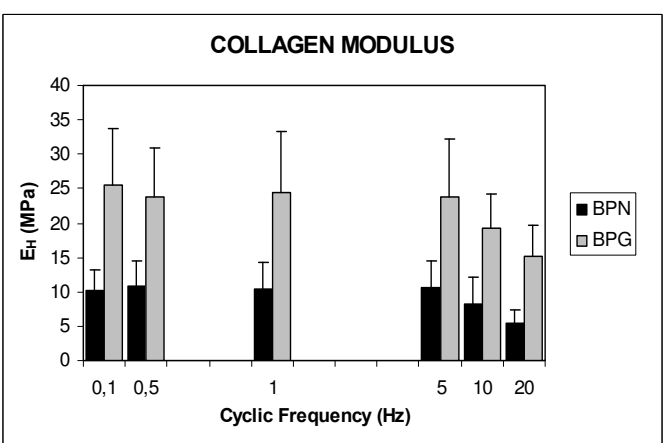

(b)

Fig. 7. (a) Typical stress-strain diagram of a pericardial tissue under uniaxial tensile cyclic loading $0.1 \mathrm{~Hz}$ demonstrating non linear mechanical behaviour. $\mathrm{E}_{\mathrm{H}}$ is the characteristic high (collagen) modulus, the tangential modulus of the second linear phase. (b) Collagen modulus of fresh natural (BPN) and glutaraldehyde treated (BPG) bovine pericardial tissue (mean \pm SE) at different cyclic loading rates

\section{Heart valve calcification}

Pathology of natural heart valve calcification causes valve dysfunction (stenosis, regurgitation, tissue rupture). A lot of possible aetiologies and mechanisms seem to be implemented in its initiation and development in human body tissues. Chronic pathologies, infections, metabolism, long term drag therapies and age related tissue degeneration, as well biochemical compounds involved in the structure of implanted biomaterials may contribute in different ways in growth of different types of calcium phosphate crystals from ions of electrolytes diluted in biological fluids, that finally deposited in valve tissue structure (Gross, 2003; Schoen \& Levy, 2005). However, despite the complicated aetiologies and mechanisms of tissue calcification, crystal growth is basically a physicochemical process of calcium and phosphate ion crystallization under certain physicochemical conditions that may be satisfied during the function of a living organism.

\subsection{Biomineralization: Physicochemical background}

Calcium phosphate deposition on implants may result from the presence of high phosphorus levels in the biological fluids in contact with the implanted surface. Due to their very low solubility products, a number of phosphate scale minerals may form in aqueous supersaturated solutions. In the order of decreasing solubility, they are listed in the following table 2. At high solution supersaturations it is possible that a number of precursor phases may be formed, depending on the solution $\mathrm{pH}$, which finally transform into the thermodynamically more stable HAP, in accordance to Ostwald's rule of stages which predicts that the least stable phase having the highest solubility is formed preferentially during a stepwise precipitation process. It is well established that kinetic factors may be more important in determining the nature and, hence, the characteristics of the solid deposits formed during the precipitation process than the respective equilibrium consideration complications that may arise from the formation of mixed solid phases, caused of the overgrowth of one crystalline phase over another. 


\begin{tabular}{|c|c|c|c|}
\hline Solid Phase & Abbrev. & Formula & $\begin{array}{l}\text { Therm.Solub. } \\
\text { Product }\end{array}$ \\
\hline $\begin{array}{l}\text { Dicalcium } \\
\text { phosphate } \\
\text { dihydrate }\end{array}$ & DCPD & $\mathrm{CaHPO}_{4} \cdot 2 \mathrm{H}_{2} \mathrm{O}$ & $1.87 \times 10^{-7}\left(\mathrm{~mol} \mathrm{~L}^{-1}\right)^{*}$ \\
\hline $\begin{array}{l}\text { Dicalcium } \\
\text { phosphate } \\
\text { anhydrous }\end{array}$ & DCPA & $\mathrm{CaHPO}_{4}$ & $9.2 \times 10^{-7}\left(\mathrm{~mol} \mathrm{~L}^{-1}\right)^{*}$ \\
\hline $\begin{array}{l}\beta . \text { Tricalcium } \\
\text { phosphate }\end{array}$ & TCP & $\mathrm{Ca}_{3}\left(\mathrm{PO}_{4}\right)_{2}$ & $2.8 \times 10^{-9}\left(\mathrm{~mol} \mathrm{~L}^{-1}\right)^{* *}$ \\
\hline $\begin{array}{l}\text { Octacalcium } \\
\text { phosphate }\end{array}$ & OCP & $\mathrm{Ca}_{8} \mathrm{H}_{2}\left(\mathrm{PO}_{4}\right)_{6} .5 \mathrm{H}_{2} \mathrm{O}$ & $2.5 \times 10^{-99}\left(\mathrm{~mol} \mathrm{~L}^{-1}\right)^{\star \star *}$ \\
\hline Hydroxyapatite & HAP & $\mathrm{Ca}_{10}\left(\mathrm{PO}_{4}\right)_{6}(\mathrm{OH})_{6}$ & $5.5 \times 10^{-118}\left(\mathrm{~mol} \mathrm{~L}^{-1}\right)^{* * * *}$ \\
\hline Defect Apatites & & $\begin{array}{l}\mathrm{Ca}_{10-x}\left(\mathrm{HPO}_{4}\right)_{x}\left(\mathrm{PO}_{4}\right)_{6-x}(\mathrm{OH})_{2-x} \\
(\mathrm{o} \leq \mathrm{x} \leq 2)\end{array}$ & \\
\hline
\end{tabular}

Table 2. Calcium phosphate crystalline phases, formulae and corresponding thermodynamic solubility products. *(Hench \& Wilson, 1991), **(Eanes et al., 1965), ***(LeGeros et al., 1975), ${ }^{* * *}$ (Betts \& Posner, 1974)

The tendency for a particular calcium phosphate phase to form in supersaturated aqueous media may be determined from the solubility phase diagrams such as the diagram shown in figure 8 . It has been reported that when calcium phosphate is precipitated from highly supersaturated solutions forms an unstable precursor phase. This phase is characterized by the absence of peaks in the powder x-ray diffraction pattern and is known as the amorphous calcium phosphate $(\mathrm{ACP})$. The composition of ACP appears to depend upon the precipitation conditions and is usually formed in supersaturated solutions at $\mathrm{pH}>7.0$ (Betts \& Posner, 1974; Eanes et al., 1965; LeGeros et al., 1975; Newesely, 1966). In slightly acidic calcium phosphate solutions the monoclinic DCPD is formed (Bets \& Posner, 1974; Brown \& Lehr, 1959). OCP is formed by the hydrolysis of DCPD in solutions of $\mathrm{pH} 5-6$ and may also be precipitated heterogeneously upon TCP (Brown et al., 1957). HAP is the thermodynamically most stable phase and often, when precipitated in the presence of foreign ions, substitution of calcium, phosphate and/or hydroxyls by some of these ions take place. Thus, substitutions of $\mathrm{OH}^{-}$by $\mathrm{F}^{-}$or $\mathrm{Cl}^{-}$ions, of the phosphate by sulfate and carbonate and of the calcium by $\mathrm{Sr}^{2+}, \mathrm{Mg}^{2+}$ and $\mathrm{Na}^{+}$ions have been reported (Heughebaert et al., 1983; Legeros R.Z \& Legeros J.P., 1984; Moreno \& Varughese, 1981; Nathan, 1984).

A considerable amount of the work done for the identification of calcium phosphate minerals which precipitates spontaneously has been based on the stoichiometric molar ratio of calcium to phosphate calculated from the respective changes in the solutions. This ratio has been found in several cases to be $1.45 \pm 0.05$ which is considerably lower than the value of 1.67 corresponding to HAP which is generally implied as the precipitating mineral. A number of different precursor phases have been postulated to be formed including TCP (Montel et al., 1981; Narasaraju \& Phebe, 1996; Walton et al., 1967), OCP (Eanes \& Posner, 1968, Posner, 1969) and DCPD (Furedi-Milhofer et al., 1976). On the basis of the analysis of the induction times preceding the spontaneous precipitation of calcium phosphate, it was concluded that at high solution supersaturations the initially forming ACP was converted into an apatitic mineral through an OCP precursor phase formation (Fransis \& Webb, 1971). 


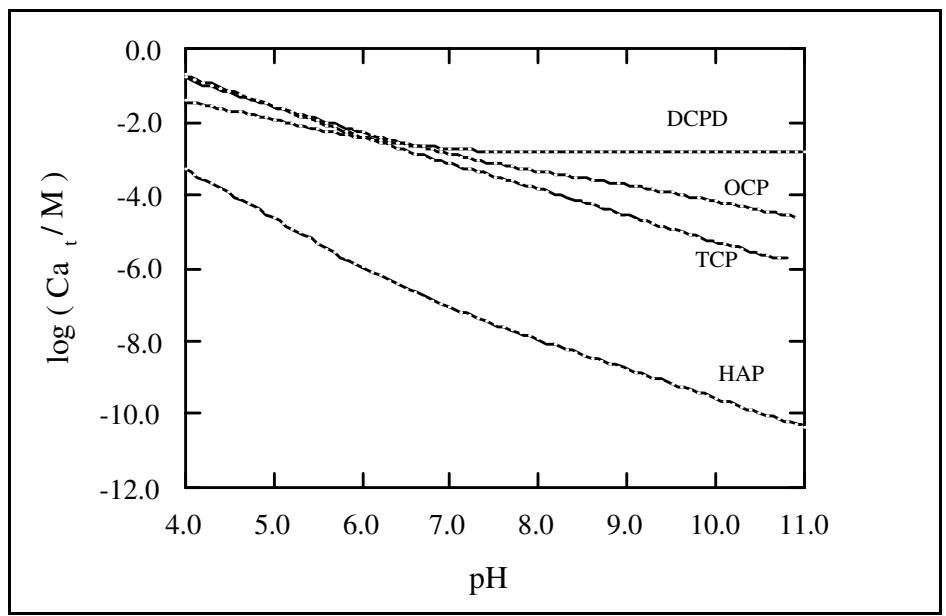

Fig. 8. Solubility isothems for calcium phosphate phases at $25^{\circ} \mathrm{C}$, Ionic strength $0.1 \mathrm{M} \mathrm{NaCl}$

Spontaneous precipitation investigations have been faced with the problem that at high supersaturations the ACP forming initially results in a rapid decrease of the calcium and phosphate ion activities which fall bellow the values needed for the spontaneous formation of other calcium phosphate phases. A careful analysis of the precipitation of calcium phosphate over the $\mathrm{pH}$ range 5.0-8.0 suggested that the limiting ion activity product for $\mathrm{ACP}$ was constant as expected for a discrete mineral phase. Moreover it has also been shown that the presence of magnesium in the precipitation medium promoted the formation of DCPD at the expense of ACP (Feenstra \& de Bruyn, 1979; Posner et al., 1984).

The driving force for the formation of a solid phase in a continuous aqueous phase is the solution supersaturation which can be developed in many ways including temperature fluctuation, $\mathrm{pH}$ change, mixing of incompatible waters, increasing the concentration by evaporation or solid dissolution etc. Although supersaturation is the driving force for the formation of a salt, the exact values in which precipitation occurs are quite different from salt to salt and as a rule, the degree of supersaturation needed for a sparingly soluble salt is orders of magnitude higher than the corresponding value for a soluble salt. For sparingly soluble salts $M_{v+} A_{v-}$ the supersaturation ratio, $S$, is defined as:

$$
S=\left\{\frac{\left(a_{M^{m+}}\right)_{S}^{v+}\left(\alpha_{\mathrm{A}^{\alpha-}}\right)_{s}^{v-}}{\left(a_{M^{m+}}\right)_{\infty}^{v+}\left(a_{A^{a-}}\right)_{\infty}^{v-}}\right\}=\left(\frac{I P}{K_{s}^{o}}\right)^{1 / v}
$$

where subscripts $s$ and $\infty$ refer to solution and equilibrium conditions respectively, $a$ denote the activities of the respective ions and $\nu_{+}+v_{-}=v . I P$ and $K_{s}{ }^{0}$ are the ion products in the supersaturated solution and at equilibrium respectively.

The fundamental driving force for the formation of a salt from a supersaturated solution is the difference in chemical potential of the solute in the supersaturated solution from the respective value at equilibrium:

$$
\Delta \mu=\mu_{\infty}-\mu_{s}
$$


Since the chemical potential is expressed in terms of the standard potential and the activity, $a$, of the solute:

$$
\mu=\mu^{o}+R T \ln a
$$

where $R$ and $T$ are the gas constant and the absolute temperature respectively. Substitution of eq. (3) to eq.(2) gives for the driving force for solid deposition (Mullin, 1993):

$$
\frac{\Delta \mu}{R T}=\ln \left(\frac{a_{s}}{a_{\infty}}\right)=\ln S
$$

For electrolyte solutions the mean ionic activity is taken:

$$
a=a_{ \pm}^{v}\left(v=v_{+}+v_{-}\right)
$$

and

$$
\frac{\Delta \mu}{R T}=\ln \left(\frac{\alpha_{ \pm, s}}{\alpha_{ \pm, \infty}}\right)^{\frac{1}{v}}=\ln S
$$

\subsection{Crystal growth in heart valves}

Degeneration of the leaflet tissue, together with calcification constitutes the principal reasons for bioprosthetic valve failure (Schoen et al., 1992). Calcification consists as already mentioned in the formation of sparingly soluble salts of calcium phosphate due to the presence of high levels of calcium and phosphate in blood serum (Schneck, 1995). Although the calcific deposits consist of apatitic calcium phosphate (HAP containing mainly carbonate, fluoride, magnesium and sodium) the formation of transient precursor phases such as DCPD and OCP is possible, as in vitro studies have shown (Brown et al., 1957; Heughebaert et al., 1983; Moreno \& Varughese, 1981). The formation of calcium phosphates on porcine heart valves to a percentage of $30-50 \%$ is responsible for their dysfunction after 12-15 years due to stenosis or insufficiency (Narasaraju \& Rao, 1979).

Despite the fact that the thermodynamic driving force in blood serum for nucleation and growth is sufficiently high for the homogeneous formation of calcium phosphates, the process is believed to be heterogeneous as dead cell remnants, lipids or degenerative collagen fragments may provide active sites for heterogeneous nucleation. Chemical treatment of porcine and pericardial bioprosthetic valves with glutaraldehyde is considered as one of the main causes of valve calcification (Hammersmeister et al., 1993; Schoen \& Levy, 1992). Despite intensive research of the past few decades, the mechanism of initiation and development of calcific deposits on tissues in contact with blood is still poorly understood. As a result the development and production of biological valves resistant to calcification is still a major challenge (Grabenwoger et al., 1996; Schoen et al, 1987). Biological, chemical and mechanical factors seem to play a significant role in the kinetics of the process of calcification (Zipkin, 1970).

\subsection{Models of heart valve calcification}

Heart valve calcification is a slow process, difficult to be studied in vivo in humans. Various animal models, like the rat subcutaneous implantation, have been used for simulation of 
biological environment but in accelerated process conditions, in order to study calcification mechanisms. In vitro calcification models have also proposed. These models have the advantage of studying the role of isolated or group of parameters that may contribute in calcification. Both models are very useful especially as pre-screening methods for studying the efficacy of various anticalcification treatments proposed (Bailey et al., 2004; Gross, 2003; Kapolos et al., 1997; Krings et al., 2009; Schoen \& Levy, 2005).
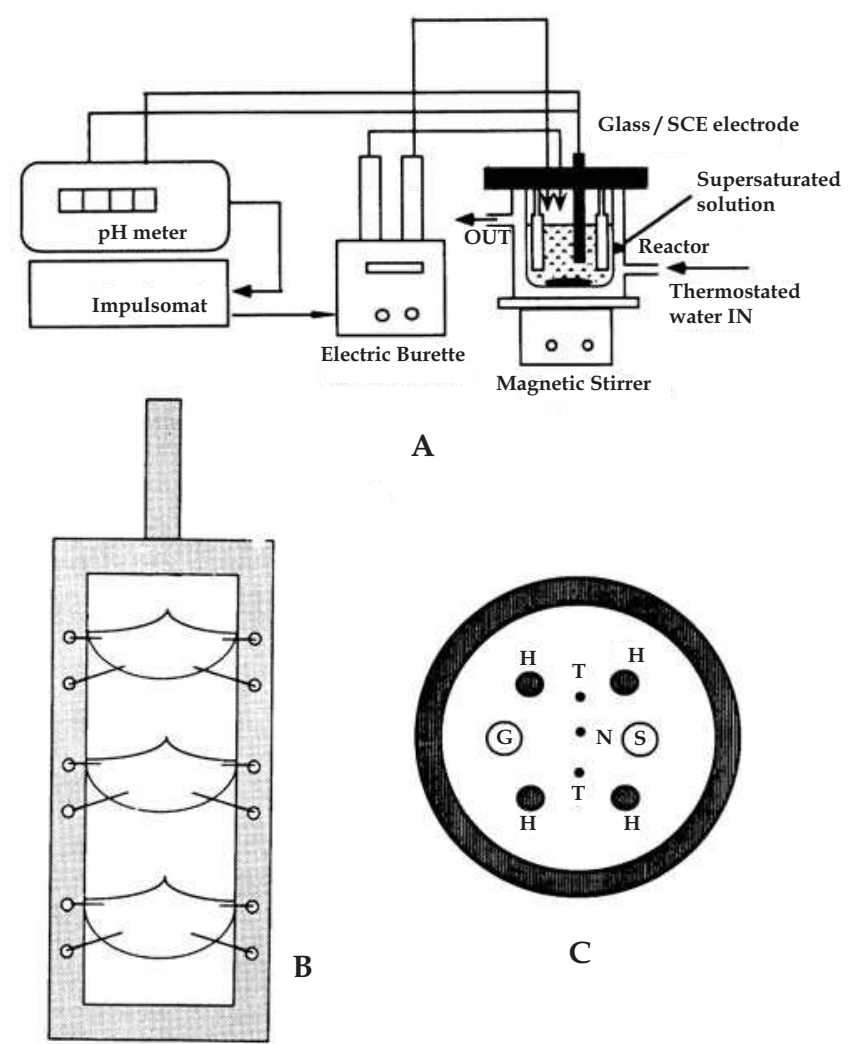

A

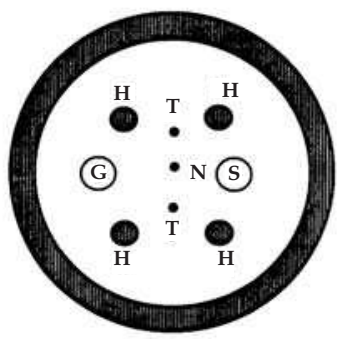

C

Fig. 9. Experimental set-up for the quantitative investigation of the calcification of heart valves in vitro. (A) Automatic titrator apparatus (B) Mounting of heart valves (C) Lid of the reactor (Kapolos et al., 1997)

The use of various model experimental procedures has resulted in the suggestion that the calcification is initiated at the matrix vesicles (Anderson, 1983; Wuthier, 1982), by acid phospholipids (Boskey, 1981; Boskey \& Posner, 1977) or by heterogeneous nucleation of various calcium phosphate phases in the body fluids considered as aqueous solutions supersaturated with respect to the salts formed (Kim \& Trump, 1975; Dallas et al., 1989; Schoen et al., 1985; Brown et al., 1988; Grott et al., 1992). Despite intensive research, it seems that there is no agreement on the mechanism of formation of calcific deposits. As a result, the evaluations of bioprosthetic materials used for cardiac valve replacements are often met 
with not unfounded criticism. One of the most successful experimental models presented, which is appropriate for the in vitro investigation of mineralization processes is the constant supersaturation model introduced and further developed by Nancollas and co-workers (Thomson \& Nancollas, 1978; Amzad et al., 1978). This methodology allows for the solution supersaturation to be kept constant by the addition of titrant solutions. The concentrations of the reagents in these solutions are calculated so that full replacement of the precipitated mass is ensured. In the case of tests performed on the mineralization of heart valves the rates obtained from this system were proportional to the solution's supersaturation.

An in vitro model, based in the constant supersaturation model was introduced in 1997 in our laboratories for the investigation of heart valve calcification in vitro. The experimental set-up is shown in figure 9. Porcine aortic heart valves, treated with glutaraldehyde were sutured on Plexiglas ${ }^{\circledR}$ frames to be kept in flat position during stirring. The frames were immersed in supersaturated solution with respect to calcium and phosphate ions in near physiological concentrations, at $37^{\circ} \mathrm{C}$. Solution's $\mathrm{pH}$ drop, associated with initiation of crystal growth deposited out of solution, triggered titrant addition with movement of computer controlled syringe pumps.

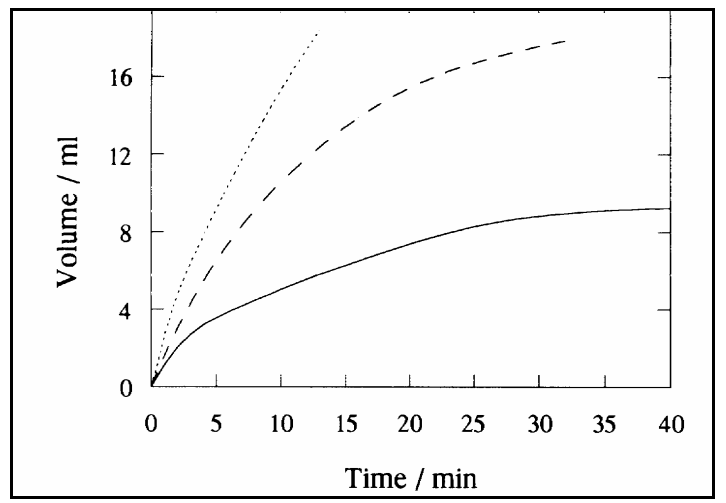

Fig. 10. Titrant addition for maintaining constant supersaturation during the course of mineralization of artificial heart valves. The rates were increased with increasing solution supersaturation ( $\sigma=0.72,1.09,1.25$ from the lower to the upper curve respectively)

Figure 10 presents experimental recordings of titrant volume added with time, in order to maintain solution's supersaturation constant. The signal from a $\mathrm{pH}$ drop sensitive device resulted from the growth of calcium phosphate crystals precipitated out of the solution, triggered titrant addition in small time steps. The diagrams correspond to different solution supersaturations. The mineral phase deposited on the glutaraldehyde treated porcine valves was identified as OCP, hydrolysed partially to HAP. The extent of hydrolysis was larger at the lower supersaturations, while at higher supersaturations with respect to OCP, this phase was stabilized, as may be seen in the scanning electron micrographs shown in figure11a-c. The characteristic plate like crystals are clearly seen in figure 11b.The rates, calculated from the titrants addition rates and normalized per unit geometric surface area of the exposed valves, were fitted to the semi empirical equation:

$$
R_{g}=k_{g} f(S) \sigma^{n}
$$


where $k_{g}$ is the rate constant for crystal growth, $f(S)$ a function of the total number of the growth sites available and $n$ the apparent order of the crystal growth process. Logarithmic plots according to eq.7 yielded the kinetics shown in figure 12. The practical implications of this finding is that the deposition of the mineral phase on the membrane matrix is controlled by the diffusion of the growth units on the OCP nuclei been formed.
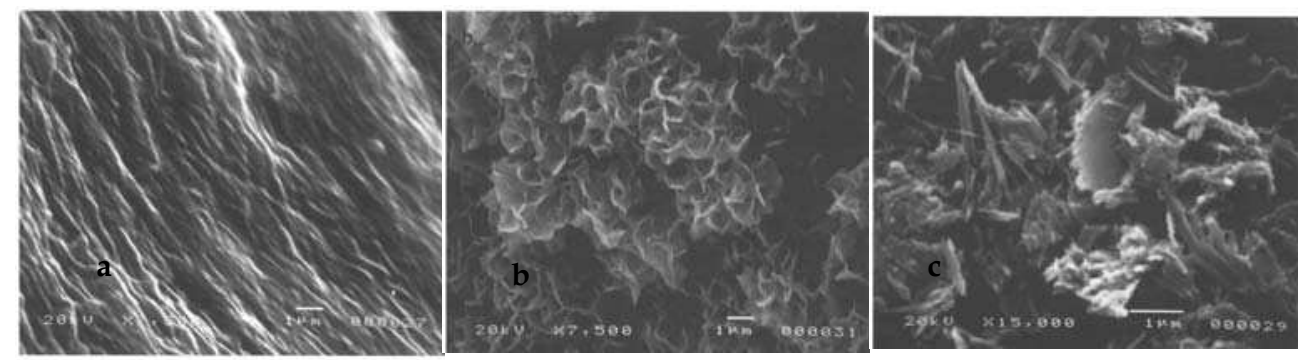

Fig. 11. Scanning electron micrographs of : (a) surface of the valves (b) OCP deposited on the valves at higher relative supersaturation and (c) OCP+HAP on valves at low relative supersaturation

Possible strategies aiming at the retardation of the calcification process should therefore rely on the alteration of the surfaces so as to make surface integration more difficult. An additional feature revealed by the kinetics plots at constant supersaturation (figure 12) is that the glutaraldehyde treated porcine valves are substrates favoring the mineral nucleation and growth.

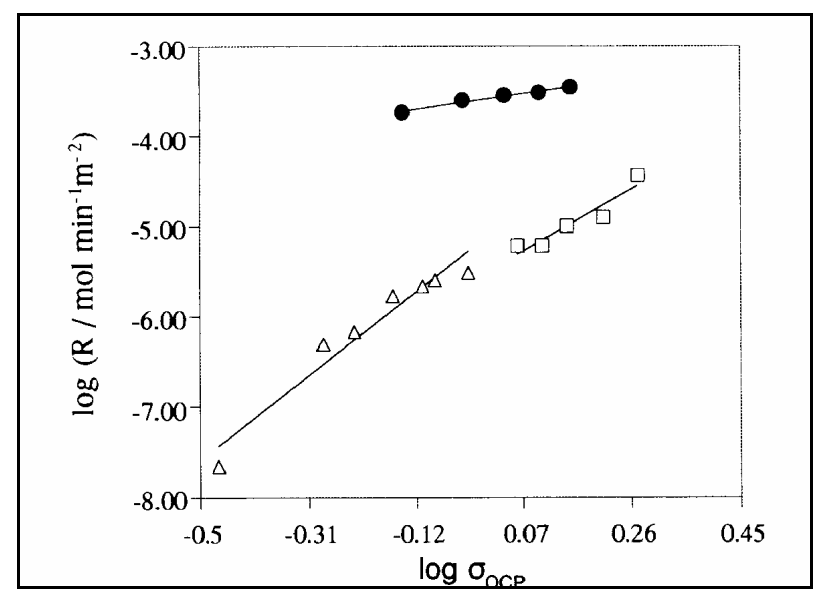

Fig. 12. Logarithm of the rate of OCP formation on glutaraldeyde treated porcine valves (black circles) as a function of the relative solution supersaturation; $\mathrm{pH} 7.4,37^{\circ} \mathrm{C}, 0.15 \mathrm{M}$ $\mathrm{NaCl}$. Open squares and triangles refer to literature results. Experiments performed in our laboratory with the same methodology on fresh, untreated porcine valves have shown that these tissues failed to induce any formation of calcium phosphate deposits although they were kept in the mineralizing solution for as long as four days 
Comparison with data obtained for OCP synthetic crystals (Tomazic et al., 1989) and collagen of various types (Heughebaert \& Nancollas, 1984; Combes, 1996) showed that glutaraldehyde treated porcine valves accelerated the formation of OCP. The significantly larger value of the rate constant suggested that in this case the number of active sites is not possibly a function of the available surface area. Structural factors on a molecular level should also be considered. Calcium phosphate crystal growth and crystal phases transformations obtained from the results of our in vitro model have been well correlated with similar results obtained from microscopic examinations, chemical analysis and spectrophotometric characterization of crystal phases on samples from calcified natural and bioprosthetic heart valves (Mikroulis et al., 2002). From the composition, the morphology and the size of the developed crystals their nature was determined by comparison with reference synthetic calcium phosphate phases. With this technique it was possible to determine the morphology of CDs developed at the internal sites of the tissue at high magnifications. It seems that in cases of natural heart valves the CDs are mixture of HAP $\left(\mathrm{Ca}: \mathrm{PO}_{4}=1.67\right)$ and OCP $\left(\mathrm{Ca}: \mathrm{PO}_{4}=1.33\right)$, while in bioprosthetic CDs the percentage of OCP is higher than of native in which the ratio $\mathrm{Ca}: \mathrm{PO}_{4}(1,82)$ is close to the Ca: $\mathrm{PO}_{4}$ composition of mature physiological biomineral in bone $(1,75)$.

As an overall conclusion from combined studies examined CDs from calcified valve leaflets in vitro, in animal models and in vivo, a model of development of calcification by crystal growth through the formation of precursor phases, which are gradually hydrolyzed in smaller in size, thermodynamically more stable crystal formations may be introduced. According to this, initiation of calcification may be supposed to take place in sites of heterogenous nucleation, formed in different tissue deficiencies, together with local changes in already highly supersaturated body fluids. This model can be very useful in the introduction of anticalcification therapies or techniques for better biomaterials.

\section{Conclusion}

Heart valve calcification is still a serious complication for a great number of patients, especially in economical active ages and the elderly. Although anticalcification therapies and procedures have been introduced for valve repair, valve replacement, especially that of aortic and mitral valves is the last choice. Unfortunately, till today there is no "ideal" aortic valve prosthesis. The latter would be easy to be implanted, possess long-term durability, would have no thrombogenicity, maximum effective orifice area, without haemolysis, "resistant" to infective endocarditis, and produce minima noise (Birkmeyer et al., 2000). Currently, available options for the patient include mechanical valve, stented or stentless biologic heterograft valves, allograft valves and pulmonary autograft valves. For the selection between mechanical and biologic valve the surgeon should balance the risks and benefits of each model. The mechanical valve has a long-term durability (till 35-40 years), but on the other hand its thrombogenicity is high, $2-4 \%$ per year. In addition, the administered anticoagulation has a significantly increased risk of bleeding. The biologic valve has an increased risk of degeneration, as its durability lasts not more than 10-12 years after implantation (Siddiqui et al., 2009). After this time, a significant regurgitation demands its replacement with an increased operative mortality in comparison to the initial implantation (about two-fold higher). On the other hand, the thrombogenicity of the biologic valve is lower than of mechanical ones, about $1 \%$ per year (Puvimanasinghe et al., 2003). Analyses based on mathematical models of data suggest that the selection of $3^{\text {rd }}$ - 
generation biologic valve for patients at about 60 years of age derive improved life expectancy and event-free expectancy regardless of the need for concomitant coronary artery surgery (Birkmeyer et al., 2000). Of course, for special patient groups the indications should be changed. Patients who do need a long-term anticoagulation such as those with chronic atrial fibrillation, intracardiac thrombus, history of thromboembolic events, hypercoagulable state or low ejection fraction, should receive a mechanical valve regardless of age. In the contrary, patients with contraindication to anticoagulants, with bleeding disorders, women of child-bearing age, should receive a biologic valve (Bonow et al., 2006). Patients with chronic renal failure have a higher risk of earlier bioprosthetic valve degeneration, and also an increased incidence of anticoagulation-related complications. For that reason, the current ACC/AHA guidelines (2006) do not recommend the routine use of a mechanical prosthesis (Bonow et al., 2006).

\section{The future: Tissue engineering (TE)}

Artificial devices designed and manufactured for mid and long term implantation in patients has to satisfy quality criteria of biocompatibility and function during all implantation time expected. This time period is varied, from a few months, for temporary used prostheses, like some orthopaedic fixation plaques and screws, to long life function, as in the case of prosthetic heart valves. Despite of their evolution and future trends, even if medical technology could make implants satisfying that criteria, prosthetic devices made of, in its best, biologically inert biomaterials cannot meet a serious clinical problem: they cannot follow changes in patient's body from the time of implantation to end of their expected life. In other words, they cannot grow up and remodelled with patient. Tissue engineering is a recent technological approach in the construction of artificial implants that can be gradually remodelled into the patient in real living tissue and organs, following regeneration and auto repair capabilities similar to that of the other natural patient body components (Kretlow \& Mikos, 2008; Zilla et al., 2008). Attempts for the construction of TE implants are spread to different tissues and organs, like dermal parches, cartilage, bone and cardiovascular implants and TE or hybrid organs like pancreas or liver. Design and construction of cardiovascular TE implants, like heart valves and blood vessels, is still a challenge because of numerous worldwide needs and the severity of possible failure.

As a general rule TE valves composed of two groups of biomaterials. One group is composing the scaffold, a structure having the morphology of natural heart valves, usually a biodegradable flexible composite synthetic membrane of a polymeric fibber network embedded in amorphous organic matrix. Different structure of valve parts like valve ring, wall stent and leaflets give to the synthetic valve mechanical strength and flexibility identical to function like natural heart valves. However, scaffolds have a temporary role as, in addition and in parallel with their normal physiological function as heart valves, they may have the ability to support cell adhesion in their structure. Different cells, like fibroblasts, smooth muscle cells and endothelia may adhere, proliferate, stimulated and function into the scaffold valve structure to produce different tissue components that will synergy to compose suitable valvular tissue. Some of these valve cells are transported into scaffold material prior implantation, followed by in vitro cell culture and parallel mechanical valve function in special designed devices, bioreactors. A hybrid structure of synthetic and living biomaterials is made in vitro, which by implantation in the living organism is expected to continue remodelling into real living tissue and organ. As the final 
form, a natural living heart valve, without any synthetic scaffold components is expected to replace the fully biodegraded initially implanted heart valve device (Flanangan \& Pandit, 2003; Ye et al., 2000; Jockenhoevel et al., 2001). Key factors for succession of such an approach are:

- Biocompatibility and mechanical function of scaffold.

- Rate and products of biodegradation.

- Functionalization of scaffold to enhance cell adhesion.

- Selection of initial cell population suitable for in vitro cell culture. Non differentiated cells, like bone marrow or umbilical cord derived stem cells, seem to be advantageous in responding to biochemical environment and stimulation in bioreactors, towards differentiation to cells needed for the in vitro synthesis of initial components of valvular tissue.

Understanding of cell-biomaterial-biomechanics interaction needs a multidisciplinary synergism in order to result in successful TE valve, avoiding possible future undesirable side effects, like valve failure or carcinogenesis.

\section{References}

Amjad Z, Koutsoukos P.G., Tomson M.B. \& Nancollas G.H. (1978). The growth of hydroxyapatite from solution. A new constant composition method. J.Dent. Res.Vol. 57,pp.909-910.

Anderson H.C. (1983). Calcific diseases. A concept. Arch. Pathol. Lab. Med. Vol.107, pp.341348.

Angell W.W, Bush W.S. \& Iben B.A. (1972). Formalin preservation of porcine heterografts. In Biological tissue in heart valve replacemen,. Ionescu M.I., Ross D.N. \& Wooler G.H., Ch.23;pp.543-552, Butterworths London.

Barratt-Boyes B.G. (1964). Homograft aortic valve replacement in aortic incompetence and stenosis. Thorax Vol. 19;pp.129-131.

Binet J., Duran C., Carpentier A. \& Langlois J. (1965). Heterologous aortic valve transplantation. Lancet Vol.286; pp.1275.

Birkmeyer N., Birkmeyer J., Tosteson A. et al. (2000). Prosthetic valve type for patients undergoing aortic valve replacement: a decision analysis. Ann Thorac Surg, Vol.70;pp.1946-1962.

Betts F. \& Posner A.S. (1974). An X-ray radial distribution study of amorphous calcium phosphate. Mater. Res. Bull., Vol.9;pp.907-914.

Boskey A.L. \& Posner A.S. (1977). The role of synthetic and bone extracted Ca-phospholipidphosphate complexes in hydroxyapatite formation. Calcif. Tissue Res. Vol.18;pp.155160.

Boskey A.L. (1981) Current concepts of the physiology and biochemistry of calcification. Clin. Orthop. Vol.157;pp.225-238 .

Bosmans J., Kefer J., De Bruyne B. et al. (2011). Procedural, 30-day and one year outcome following CoreValve or Edwards transcatheter aortic valve implantation: results of the Belgian national registry. Interactive CardioVascular and Thoracic Surgery. Vol.12(5);pp.762-767.

Bonow R.O., Carabello B., de Leon A.C.Jr. et al. (1998).ACC/AHA guidelines for the management of patients with valvular heart disease: a report of the American 
College of Cardiology/ American Heart Association Task Force on Practice Guidelines (Committee on Management of Patients With Valvular Heart Disease). JACC Vol.32;pp.1486 -1588.

Brener S.J., Duffy C., Thomas J.D. et al. (1995). Progression of aortic stenosis in 394 patients: relation to changes in myocardial and mitral valve dysfunction. J Am Coll Cardiol. Vol.25:pp.305-310.

Brown W.E., Lehr J.R., Smith J.P. \& Frazier A.W. (1957). Crystallography of octacalcium phosphate, J. Amer. Chem. Soc. Vol.79;pp.5318-5319.

Brown W.E., Edelman N. \& Tomazic B. (1988). Octacalcium phosphate as a precursor in biomineral formation. Adv. Dent. Res. Vol.1;pp.306-312 .

Carpentier A., Lemaigre G., Robert L. et al. (1969). Biological factors affecting long-term results of valvular heterografts. J Thorac Cardiovasc Surg Vol.58;pp.467-483.

Chambers J., Roxburgh J., Blauth C. et al. (2005). A randomized comparison of the MCRI On-X and Carbomedics Top Hat bileaflet mechanical replacement aortic valves: early postoperative hemoduynamic function and clinical events. J Thorac Cardiovasc Surg Vol.130;pp. 759-764.

Combes C. (1996). Croissance Cristalline de phosphates de calcium sur des substrats d' interet biologiques: Le titane et le Collagène, Thèse, pp.55-60. INPT, Toulouse, France.

Cormier B, \& Vahanian A. (1992). Indications and outcome of valvuloplasty. Curr Opin Cardiol Vol.7;pp.222-226.

Cribier A., Elchaninoff H., Bash A. et al. (2002). Percutaneous transcatheter implantation of an aortic valve prosthesis for calcific aortic stenosis: First human case description. Circulation Vol.106;pp.3006-3008.

Dalas E., Ioannou P.V. \& Koutsoukos P.G. (1989). Effect of fatty acyl and cation content of cardiolipins on in vitro calcification. Langmuir, Vol.5;pp.157-160.

Davidson M. \& Baim D. (2008). Percutaneous aortic valve interventions. In Cardiac Surgery in the Adult, Cohn L. pp.963-968. 3rd Edition, Mc Graw Hill Medical, New YorkChicago-San Francisco.

Davidson C.J., Harrison J.K.., Leithe M.E. et al. (1990). Failure of aortic balloon valvuloplasty to result in sustained clinical improvement in patients with depressed left ventricular function. Am J Cardiol, Vol.65;pp.72-77.

Diethrich E. (1993). The treatment of aortic stenosis: is valvuloplasty ever an alternative to surgery? J Interv Cardiol,Vol.3;pp.7-13.

Eanes E.A., Gillessen I.H. \& Posmer A.S. (1965). Intermediate stages in the precipitation of hydroxyapatite. Nature, Vol.208;pp.365-367.

Eanes E.D. \& Posner A.S. (1968). Alkaline earth intermediate phases in the basic solution preparation of phosphates. Calcif. Tiss. Res., Vol.2;pp.38-48.

Edwards W. (1996). Applied anatomy of the heart. In: Mayo Clinic Practice of Cardiology, Giuliani E., Gersh B., McGoon M., Hayes D. \& Schaff H., pp. 466-468. 3 ${ }^{\text {rd }}$ Ed, Mosby St. Louis-Baltimore-Boston.

Emery R., Arom K., Kshetry V. et al. (2002). Decision making in the choice of heart valve for replacement in patients aged 60-70 years: twenty-year follow-up of the St. Jude Medical aortic valve prostheses. J Heart Valve Dis, Vol.11; (Suppl 1);pp.S37-S44. 
Emery R., Krogh C., Jones D. et al. (2004). Five-year follow-up of the ATS mechanical heart valve. J Heart Valve Dis, Vol.13;pp.231-236.

Emery R., Emery A., Knutsen A. et al. (2008). Aortic valve replacement with a mechanical cardiac valve prosthesis. In: Cardiac Surgery in the Adult. Cohn L. pp.841-854. 3rd Edition, Mc Graw Hill Medical, New York-Chicago-San Francisco.

Ezekowitz M. (2002) Anticoagulation management of valve replacement patients. J Heart Valve Dis, Vol.11, (suppl1);pp.S56-S60.

Faggiano P., Aurigemma G.P., Rusconi C. et al. (1996). Progression of valvular AS in adults: literature review and clinical implications. Am Heart J, Vol.132;pp.408 -417.

Feenstra T.P. \& de Bruyn P.L. (1979). Formation of calcium phosphates in moderately Supersaturated Solutions. J. Phys. Chem., Vol.83;pp.475-479.

Flanangan T.C. \& Pandit A. (2003). Living artificial heart valve alternatives: A review. European Cells and Materials, Vol.6;pp.28-45.

Francis M.D. \& Webb N.C. (1971). Hydroxyapatite Formation from a Hydrated calcium Monohydrogen Phosphate Precursor. Calcif. Tissue Res., Vol.6;pp.335-342.

Freeman R. \& Otto C. (2005). Spectrum of Calcific Aortic Valve Disease: Pathogenesis, Disease Progression, and Treatment Strategies. Circulation, Vol.111;pp.3316-3326.

Furedi-Milhofer H., Brecevic L. \& Purgaric B. (1976). Crystal growth and phase transformation in the precipitation of calcium phosphates, Faraday Discussions Chem. Soc., Vol.61;pp.184-190.

Gelsomino S., Morocutti G., Da Col P. et al. (2002). Preliminary experience with the St. Jude Medical Regent mechanical heart valve in the aortic position: early in vivo hemodynamic results. Ann Thorac Surg, Vol.73pp.1830-1836.

Gibbon J.H. Jr. (1954). Application of a mechanical heart and lung apparatus to cardiac surgery. Minn Med, Vol.37;pp.171-185.

Gott V., Alejo D. \& Cameron D. (2003). Mechanical heart valves: 50 years of evolution. Ann Thorac Surg, Vol.76;pp.S2230-S2239.

Grabenwoger M., Sider J., Fitzal F. et al. (1996). Impact of Glutaraldehyde on Calcification of Pericardial Bioprosthetic Heart Valve Material. Ann Thomac Surg, Vol.62;pp.772777.

Gross J.M. (2003). Calcification of bioprosthetic heart valves and its assessment. J Thorac Cardiovasc Surg, Vol. 125;pp.S6-S8.

Grott T.P., Chih P., Dorsey L.M.A. et al. (1992). Calcificationof Porcine valves: A successful new method of antimineralization. Ann Thorac Surg, Vol.53;pp.207-216.

Hall R. \& Julian D. (1989). Diseases of the cardiac valves. Churchill Livingstone, EdinburghLondon-Melbourne-New York.

Hammermeister K.E., Sethi G.K., Henderson W.G. et al. (1993). A comparison of outcomes in men 11 years after heart-valve replacement with a mechanical valve or bioprosthesis. New Engl. J Med, Vol.328;pp.189-1296.

Harken D.E., Taylor W.J., Lefemine A.A. et al., (1962). Aortic valve replacement with a caged ball valve. American Journal of Cardiology, Vol.9(2);pp.292-299.

Hench L.L. \& Wilson J. (1991). Bioceramics. Materials Research Society Bulletin, Vol.16(9);pp. 62-74.

Hess O., Villari B. \& Krayenbuehl H. (1993). Diastolic dysfunction in aortic stenosis. Circulation, Vol.87 (Suppl IV);pp.73-76. 
Heughebaert J.C., Zawacki S.J. \& Nancollas G.H. (1983). J. Crystal Growth,. Vol.63; pp.83-90.

Heughebaert J.C. \& Nancollas G.H. (1984). Kinetics of crystallization of octacalcium phosphate. J. Phys. Chem, Vol. 88;pp.2478-2481.

Hufnagel C.A. \& Harvey W.P. (1953). Surgical correction of aortic insufficiency. Bull Georgetown U Med Cenert; Vol.6;pp.60-61.

Ionescu M. \& Ross D. (1969). Heart-valve replacement with autologous fascia lata. Lancet, Vol.2;pp.335-338.

Jockenhoevel S., Zund G., Hoerstrup S.P. et al. (2001). Fibrin gel - advantages of a new scaffold in cardiovascular tissue engineering. European Journal of Cardio-thoracic Surgery, Vol.19;pp.424-430.

Kapolos J., Mavrilas D., Missirlis Y.F. \& Koutsoukos P. G. (1997). Model experimental system for investigation of heart valve calcification in vitro. J Biomed Mater Res (Appl Biomater), Vol.38;pp.183-190.

Kretlow J.D. \& Mikos A.G. (2008). 2007 AlChE Alpha Chi Sigma Award: From material to tissue: Biomaterial development, scaffold fabrication, and tissue engineering. AIChE J. Vol.54(12);pp.3048-3067.

Kim K.M. \& Trump B.F. (1975). Amorphous calcium phosphate precipitations in human aortic valve. Calcif. Tissue Res, Vol.18;pp.155-160.

Krings M., Kanellopoulou D., Koutsoukos P.G. et al. (2009). Development of a new combined test setup for accelerated dynamic $\mathrm{pH}$-controlled in vitro calcification of porcine heart valves. Int J Artif Organs, Vol.32;pp.794-801.

LeGeros R.Z., Shirra W.P., Mirawite M.A. \& LeGeros J.P., (1975). In: Physico-Chimie et Cristallographie des Apatites d' Interêt Biologique, CNRS, Colloque Internationaux, Paris.

LeGeros R.Z. \& LeGeros J.P. (1984). Phosphate minerals in human tissues, In: Phosphate Minerals, Nriagu J.O., Moore P.B.,pp. 351-385, Springer Velag, Berlin Heidelberg.

Malouf J., Edwards W., Tajik J. \& Seward J. (2008). Functional anatomy of the heart. In: Hurst's The Heart, Fuster V., O'Rourke R., Walsh R. \& Poole-Wilson P. pp.61-63. $12^{\text {th }}$ Edition, McGraw Hill, New York-Chicago-San Fransisco.

Mikroulis D., Mavrilas D., Kapolos J. et al. (2002). Physicochemical and Microscopical study of Calcific Deposits from Natural and Bioprosthetic heart Valves. Comparison and implications for mineralization mechanism. J Mater Sci: Mater Med. Vol.13;pp. 885889.

Moreno E.C. \& Varughese K.J. (1981). Crystal growth of apatites from dilute solutions, J. Crystal Growth, Vol.53;pp.20-30.

Montel G., Bonel G., Heughebaert J.C. et al. (1981). New Concepts in the Composition, Crystallization and Growth of the Mineral Component of Calcified Tissue. J. Crystal Growth, Vol.53;pp.74-99.

Mullin J.W. (1993). Crystallization, pp.118-122. 3rd Ed. Butterworth-Heinemann, Oxford.

Murray G. (1956). Homologous aortic valve segment transplant as surgical treatment for aortic and mitral insufficiency. Angiology, Vol.7;pp.466-471.

Narasaraju T.S.B. \& Phebe D.E. (1996). Some physico-chemical aspects of hydroxyapatite, J. Mater. Science, Vol.31;pp.1-21. 
Narasaraju T.S.B, Rao K.K. \& Rai U.S. (1979). Determination of solubility products of hydroxylapatite, chloroapatite and their solid solutions. Canad. J.Chem., Vol.57;pp. 1919-1922.

Nathan Y. (1984). The mineralogy and geochemistry of phosphorites. In: Phosphate Minerals, Nriagu J.O. \&, Moore P.B. pp. 275-291, Springer Verlag, Berlin Heidelberg.

Newesely H. (1966). Changes in Crystal types of low solubility calcium phosphates in of accompanying ions. Arch. Oral Biol. Sp. Suppl., 6;pp.174 .

Olsson M., Thyberg J. \& Nilsson J. (1999). Presence of oxidized low density lipoprotein in nonrheumatic stenotic aortic valves. Arterioscler Thromb Vasc Biol. Vol.19;pp.12181222.

Otto C., Lind B., Kitzman D. et al. (1999). Association of aortic-valve sclerosis with cardiovascular mortality and morbidity in the elderly. $N$ Engl J Med, Vol.341;pp. 142-147.

Oxenham H., Bloomfield P., Wheatley D. et al. (2003). Twenty-year comparison of a BjorkShilley mechanical heart valve with porcine bioprostheses. Heart Vol.89;pp.715.

Park J.B. \& Lakes R.S. (1992). Biomaterials: An Introduction. Chapter 1;pp.4. Plenum Press, NY.

Posner A.S. (1969). Crystal Chemistry of Bone Mineral. Physiol. Rev., Vol.49;pp.760-792.

Posner A.S., Blumenthal N.C. \& Betts F. (1984). Chemistry and structure of precipitated hydroxyapatites. In: Phosphate Minerals, Nriagu J.O. \& Moore P.B., pp. 330-350. Springer Verlag, Berlin Heidelberg.

Potter D., Sundt T., Zehr K. et al. (2005). Operative risk of reoperative aortic valve replacement. J Thorac Cardiovasc Surg, Vol.129;pp.94-103.

Puvimanasinghe J., Takkenberg J., Eijkemans M., et al. (2003). Choice of a mechanical valve or a bioprosthesis for AVR: does CABG matter? Eur J Cardiothorac Surg Vol.23;pp.688-695.

Rahimtoola S. (2004). Aortic valve disease. In: Hurst's The Heart, Fuster V., Wayne Alexander R.O., Rourke R., et al. pp.1644-1645. 11 th Edition, Mac Graw Hill Medical Publishing Division, New York-Chicago-San Francisco.

Rahimtoola S. (2010). Choice of prosthetic heart valve in adults. JACC Vol.55;pp.2413-2426.

Schoen F.J., Levy B.J., Nelson A.C. et al. (1985). Onset and progression of experimental bioprosthetic heart valve calcification. Lab. Invest. Vol.52;pp.523-532.

Shoen F.J., Kujovich J.L., Webb C.L. \& Levy R.J. (1987). Chemically determined mineral content of explanted porcine valve bioprostheses. Correlation with radiographic assessment of calcification and clinical data. Circulation Vol.76;pp.1061-1066.

Schoen F.J., Harasaki H., Kim K.H. et al. (1988). Biomaterial associated calcification: pathology, mechanisms and strategies of prevention. J. Biomed Mater Res: Appl Biomater Vol.22;pp.11-36.

Schoen F.J., Levy R.J. \& Piehler H.R. (1992). Pathological considerations in replacement cardiac valves. Cardiovasc. Pathol. Vol.1;pp.29-52.

Schoen F.J. \& Levy R.J. (1992). Heart valve biorpostheses antimineralization. Eur J Cardiothorac Surg Vol.6 (suppl 1);pp.91-94.

Schoen F.J. \& Levy R.J. (2005). Calcification of tissue heart valve substitutes: Progress toward understanding and prevention. Ann Thorac Surg, Vol.79;pp.1072-1080. 
Schwartz J. \& Zipes D. (2005). Cardiovascular disease in the elderly. In: Braunwald's Heart Disease, Zipes D., Libby P., O. Bonow R. \& Braunwald E. pp.1944. 7th Edition, Elsevier Saunders, Philadelphia, Penn.

Schneck D.J. (1995). An outline of cardiovascular structure and function in: The Biomedical Engineering Handbook, Bronzino J.D. pp 3-14, CRC Press Boca Raton, Fla.

Senning A. (1967). Fascia lata replacement of aortic valves. J Thorac Cardiovasc Surg Vol.54;pp.465-470.

Shiono M., Sezai Y., Sezai A., et al. (2005). Long-term results of the cloth-covered StarrEdwards ball valve. Ann Thorac Surg Vol.80;pp.204.

Siddiqui R., Abraham J., Butany J. (2009). Bioprosthetic heart valves: modes of failure. Histopathology Vol.55pp.135-44.

Simionescu, D., Simionescu, A., Deac, R. (1993). Mapping of glutaraldehyde-treated bovine pericardium and tissue selection for bioprosthetic heart valves. J Biomed Mater Res Vol.27;pp.697-704.

Smedira N., Ports T., Merrick S., et al. (1993). Balloon aortic valvuloplasty as a bridge to aortic valve replacement in critically patients. Ann Thorac Surg, Vol.55;pp.914.

Starr A., Edwards W., McCord M. et al. (1963). Aortic replacement. Circulation Vol.27;pp.779.

Stewart B.F., Siscovick D., Lind B.K. et al. (1997). Clinical factors associated with calcific aortic valve disease: Cardiovascular Health Study. J Am Coll Cardiol. Vol.29;pp.630 634 .

Stewart W. (1998). Intraoperative echocardiography. In: Textbook of Cardiovascular Medicine, Topol E. pp.1497-1525. Lippincott-Raven: Philladelphia.

Tomazic B.B., Brown W.E. \& Schoen F.J. (1989). Physicochemical characterization of bioprosthetic heart valve calcific deposits. Calcified Tissue Int. Vol.46;pp.S94.

Tomson M.B. \& Nancollas G.H. (1978). Mineralization kinetics: a constant composition approach, Science, Vol.200;pp.1059-1060.

Wallby L., Janerot-Sjoberg B., Steffensen T. et al. (2002). T lymphocyte infiltration in nonrheumatic aortic stenosis: a comparative descriptive study between tricuspid and bicuspid aortic valves. Heart. Vol.88;pp.348 -351.

Walther T., Falk V., Tiggers R. et al. (2000). Comparison of On-X and SJM HP bileaflet aortic valves. J Heart Valve Dis Vol.9;pp.403-407.

Walton A.G., Badin W.J., Furedi, H. \& Schwarz A. (1967). Nucleation of calcium phosphate from solution. Canad. J. Chem., Vol.45;pp.2696-2701.

Williams P., Warwick R., Dyson M. \& Bannister L. (1989). Gray's Anatomy, 37th Edition, Churchill Livingstone, Edinburg-London-Melbourne and New York.

Woodroof A.E. (1972). The chemistry and biology of aldehyde treated tissue heart valve xenografts. In: Biological tissue in heart valve replacement, Ionescu M.I., Ross D.N. \& Wooler G.H.,Ch.10;pp.347-362. Butterworths London.

Wuthier R.E. (1982). A review of the primary mechanism of endochondrial calcification with special emphasis on the role of cells, mitochondria and matrix vesicles. Clin.Orthopad, Vol.169;pp.219-252.

Ye Q., Zund G., Benedikt P. et al. (2000). Fibrin gel as a three dimensional matrix in cardiovascular tissue engineering. European Journal of Cardio-thoracic Surgery, Vol.17;pp.587-591. 
Zilla P., Brink J., Human P \& Bezuidenhout D. (2008). Prosthetic heart valves: Catering for the few. Biomaterials, Vol. 29;pp.385-406.

Zipkin I. (1970). The inorganic composition of bones and teeth. In: Biological Calcification: Cellular and Molecular Aspects, Schraer H. pp.69-103, Appleton Century Crofts, New York. 


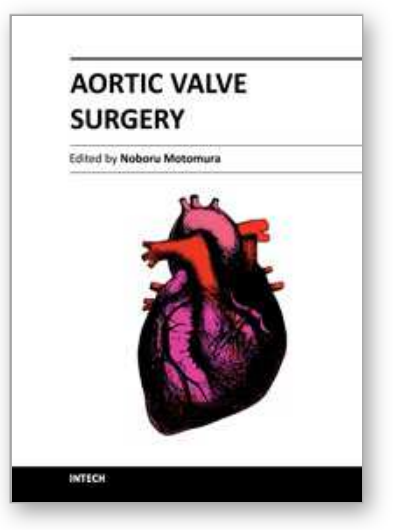

\author{
Aortic Valve Surgery \\ Edited by Prof. Noboru Motomura
}

ISBN 978-953-307-600-3

Hard cover, 246 pages

Publisher InTech

Published online 22, December, 2011

Published in print edition December, 2011

The aortic valve is located at the center of the heart. It is the core of cardiac anatomy and aortic valve surgery has led the field of cardiac surgery. This book describes all aspects of aortic valve surgery and it will help clarify daily questions regarding the clinical practice in aortic valve surgery, as well as induce inspiration and new insights into this field.

\title{
How to reference
}

In order to correctly reference this scholarly work, feel free to copy and paste the following:

Dimosthenis Mavrilas, Efstratios Apostolakis and Petros Koutsoukos (2011). Prosthetic Aortic Valves: A Surgical and Bioengineering Approach, Aortic Valve Surgery, Prof. Noboru Motomura (Ed.), ISBN: 978-953307-600-3, InTech, Available from: http://www.intechopen.com/books/aortic-valve-surgery/prosthetic-aorticvalves-a-surgical-and-bioengineering-approach

\section{INTECH}

open science | open minds

\section{InTech Europe}

University Campus STeP Ri

Slavka Krautzeka 83/A

51000 Rijeka, Croatia

Phone: +385 (51) 770447

Fax: +385 (51) 686166

www.intechopen.com

\section{InTech China}

Unit 405, Office Block, Hotel Equatorial Shanghai

No.65, Yan An Road (West), Shanghai, 200040, China

中国上海市延安西路65号上海国际贵都大饭店办公楼 405 单元

Phone: +86-21-62489820

Fax: +86-21-62489821 
(C) 2011 The Author(s). Licensee IntechOpen. This is an open access article distributed under the terms of the Creative Commons Attribution 3.0 License, which permits unrestricted use, distribution, and reproduction in any medium, provided the original work is properly cited. 